\title{
Effect of seasonally changing tissue weight on trace metal concentrations in the bivalve Macoma balthica in San Francisco Bay
}

\author{
Daniel J. Cain \& Samuel N. Luoma \\ U. S. Geological Survey, 345 Middlefield Road, Menlo Park, California 94025, USA
}

\begin{abstract}
The influence of seasonal changes in the weight of soft tissues on temporal fluctuations in tissue concentrations of $\mathrm{Cu}$ and $\mathrm{Zn}$ was examined in 4 populations of the clam Macoma balthica sampled in San Francisco Bay for a period of 2 to 5 yr. Fluctuations in metal concentration expected from changes in tissue weight between sampling dates were estimated by assuming that whole body metal burden was constant during the sampling interval. Comparison of estimated and actual metal concentrations showed that the degree to which fluctuations in trace metal concentrations were driven by weight changes differed considerably among stations, among years at a single station, and between metals.
\end{abstract}

\section{INTRODUCTION}

Mussels, oysters and clams have been extensively used as biological indicators of trace metal and organic contamination in the marine and estuarine environment (Phillips 1976, Bryan \& Hummerstone 1978, Goldberg et al. 1978, Martin et al. 1984, Thomson et al. 1984). These organisms typically exhibit annual growth and reproductive cycles that result in seasonal changes in soft tissue weight (Beukema \& De Bruin 1977, Zandee et al. 1980, Nichols \& Thompson 1982). Within a single' 3 to 6 mo growing season, an adult animal may increase its soft body tissue weight by a factor of 2 or more (Davis \& Wilson 1983). Much of this new growth is the result of a build-up of glycogen and lipid energy reserves and may subsequently be lost during the remainder of the year as these resources are depleted (Beukema \& De Bruin 1977, Zandee et al. 1980, Nichols \& Thompson 1982).

Seasonal changes in the tissue weight of bioindicator organisms can significantly affect trace metal concentrations by simply diluting or concentrating the animal's total metal body burden (Phillips 1976, Simpson 1979, Strong \& Luoma 1981, Lobel \& Wright 1982b, Popham \& D'Auria 1983). The extent of the effect would be expected to vary with growth rates in relation to the availability and quality of food sources (Gallucci \& Hylleberg 1976, Beukema et al. 1977) and overall environmental suitability for the organism (including levels of trace metal exposure). Methodology for quantitatively characterizing the contribution of weight change to temporal variation in metal concentrations in bivalve bioindicators is not available, however.

This paper reports on the influence of changing tissue weight on the temporal variation of trace metal concentrations in clams Macoma balthica collected from 4 stations in San Francisco Bay for a period of 2 to 5 yr. An empirical method is presented to separate fluctuations in trace metal concentrations caused by changes in the weight of soft tissues from fluctuations driven by other processes.

\section{MATERIALS AND METHODS}

Twenty to 30 adult Macoma baltica with shell lengths $\geq 10 \mathrm{~mm}$ were collected at near monthly intervals from 4 intertidal mudflats in San Francisco Bay (Fig. 1). The clams were depurated in seawater at ambient salinity and $12{ }^{\circ} \mathrm{C}$ for $2 \mathrm{~d}$. Individual shell lengths were recorded to the nearest $0.1 \mathrm{~mm}$. The sample was split into groups of individuals of similar shell length $( \pm 1.0 \mathrm{~mm})$. The range of shell lengths varied somewhat among collections, depending upon the availability of the smallest and largest clams, but most of the same size classes were represented in 


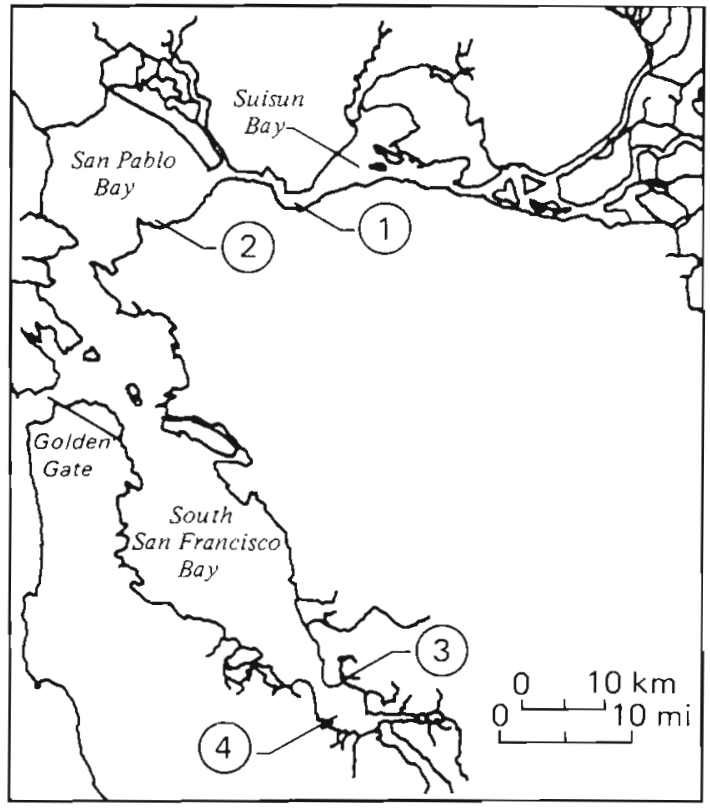

Fig. 1. San Francisco Bay showing location of sampling stations

nearly all samples. The soft tissues of each group were dissected, pooled and dried at $80^{\circ} \mathrm{C}$ to constant weight. After the dry weights were recorded, tissue samples were digested by reflux in hot $16 \mathrm{~N} \mathrm{HNO}_{3}$. When the digestion was complete, the acid was evaporated. The residue was reconstituted in $3 \mathrm{~N} \mathrm{HCl}$ and analyzed for trace metals directly by flame atomic absorption spectrophotometry.

Each time a station was sampled, correlations of tissue dry weights and shell lengths were fitted to the power function

$$
\mathrm{W}_{1}=\mathrm{a} \cdot \mathrm{L}_{1}^{\mathrm{b}}
$$

Since the sample was split by shell length, $W_{1}=$ the mean dry tissue weight per individual $(\mathrm{mg})$ in the $\mathrm{i}^{\text {th }}$ group: $L_{1}=$ the mean shell length (mm) per individual in the same group. The parameters $\mathrm{a}$ and $\mathrm{b}$ are fitted and change seasonally in relation to the annual growth cycle, but the equation always produced a statistically significant fit to the data. A typical correlation is shown in Fig. 2. Using Eq. 1, the dry weight of a clam of standard shell length (either 20 or $25 \mathrm{~mm}$, see below) was calculated for each correlation. Seasonal changes in dry tissue weight were estimated by differences among the dry weights of the standard-sized clam on different sampling dates. This approach has been used to calculate relative growth rate for populations of Macoma nasuta (Gallucci \& Hylleberg 1976).

Eq. 1 can underestimate increases in tissue weight if shell length is increasing simultaneously. For Macoma balthica in San Francisco Bay, increases in both shell length and soft tissue weight generally occur between

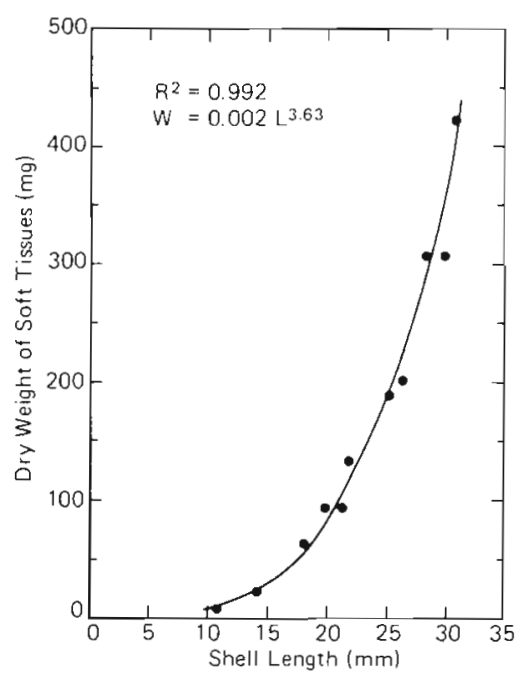

Fig. 2. Macoma balthica. Relation between dry tissue weight and shell length

February and June (Nichols \& Thompson 1982). However, the rate of shell growth is greatest in young animals and decreases as animals approach their maximum shell length (Lammens 1967, Cloern \& Nichols 1980, Nichols \& Thompson 1982). In order both to minimize the underestimation of tissue weight during periods of shell growth and to avoid extrapolation, the dry tissue measurements were standardized to the largest-sized clam that always occurred at a station. At Stations 1, 3 and 4, this was $25 \mathrm{~mm}$ and at Station 2, it was $20 \mathrm{~mm}$.

The mean metal concentration of all individuals collected at any time $\mathrm{j}(\mathrm{j}=1 \ldots \mathrm{x})$ is represented as

$$
\frac{1}{n} \sum_{i=1}^{n}\left(\frac{M_{i}}{W_{i}}\right)_{j}=\left(\frac{\bar{M}}{W}\right)_{j}
$$

where $M_{1}=$ the mass $(\mu \mathrm{g})$ of metal in the soft tissue of the $\mathrm{i}^{\text {th }}$ group of pooled individuals; $\mathrm{W}_{\mathrm{i}}=$ the dry weight of the soft tissues of that same group; $n=$ the number of groups within the sample. Because $\left(\frac{\mathrm{M}_{1}}{\mathrm{~W}_{\mathrm{i}}}\right)_{j}$ is actually the mean metal concentration for the group $i$, $(\overline{\mathrm{M}})_{j}$ is a grand mean.

The total metal content of the standard-sized clam at any time $\mathrm{j}, \mathrm{Mj}_{\mathrm{j}}$, was calculated as the product of concentration and the dry weight of a standard-sized clam, $\mathrm{W}_{\mathrm{j}}{ }^{\mathrm{i}}$ using the expression

$$
\mathrm{M}_{\mathrm{j}}^{*}=(\overline{\overline{\mathrm{M}}})_{\mathrm{j}} \cdot \mathrm{W}_{\mathrm{j}}
$$

Correlations of trace metal concentration and body size for Macoma balthica in San Francisco Bay can vary with time and place from significantly positive to significantly negative (Strong \& Luoma 1981). Where significant correlation occurs, the distribution of speci- 
men sizes in a sample may bias the grand mean metal concentration. Therefore, if the metal concentration and shell length of clams within a sample were correlated $(\mathrm{p} \leq 0.01)$, the mean concentration term in Eq. 3 was replaced by the concentration calculated from the correlation for a clam of standard shell length (Luoma \& Cain 1979, Strong \& Luoma 1981).

The difference in metal concentration between sampling dates $\mathrm{j}$ and $\mathrm{j}+1$ was partitioned into 2 terms: one describing the change in metal concentration caused by a change in tissue weight during the sampling interval and another describing the change in concentration due to a net exchange of metal by the tissues. Using the observed concentration at $\mathrm{j}$, the concentration due solely to a change in tissue weight was estimated by the expression

$$
\left(\frac{\hat{M}}{\mathrm{~W}}\right)_{j+1}=\left(\frac{\bar{M}}{\bar{W}}\right)_{j} \cdot\left(\frac{W_{j}^{*}}{W_{j+1}^{*}}\right)
$$

where $\left(\frac{\hat{M}}{\mathrm{~W}}\right)_{j+1}=$ the estimated concentration at $\mathrm{j}+1$; $\left(\frac{\bar{M}}{W}\right)_{j}=$ the observed concentration at $j ; W_{j}$ and $W_{j+1}$

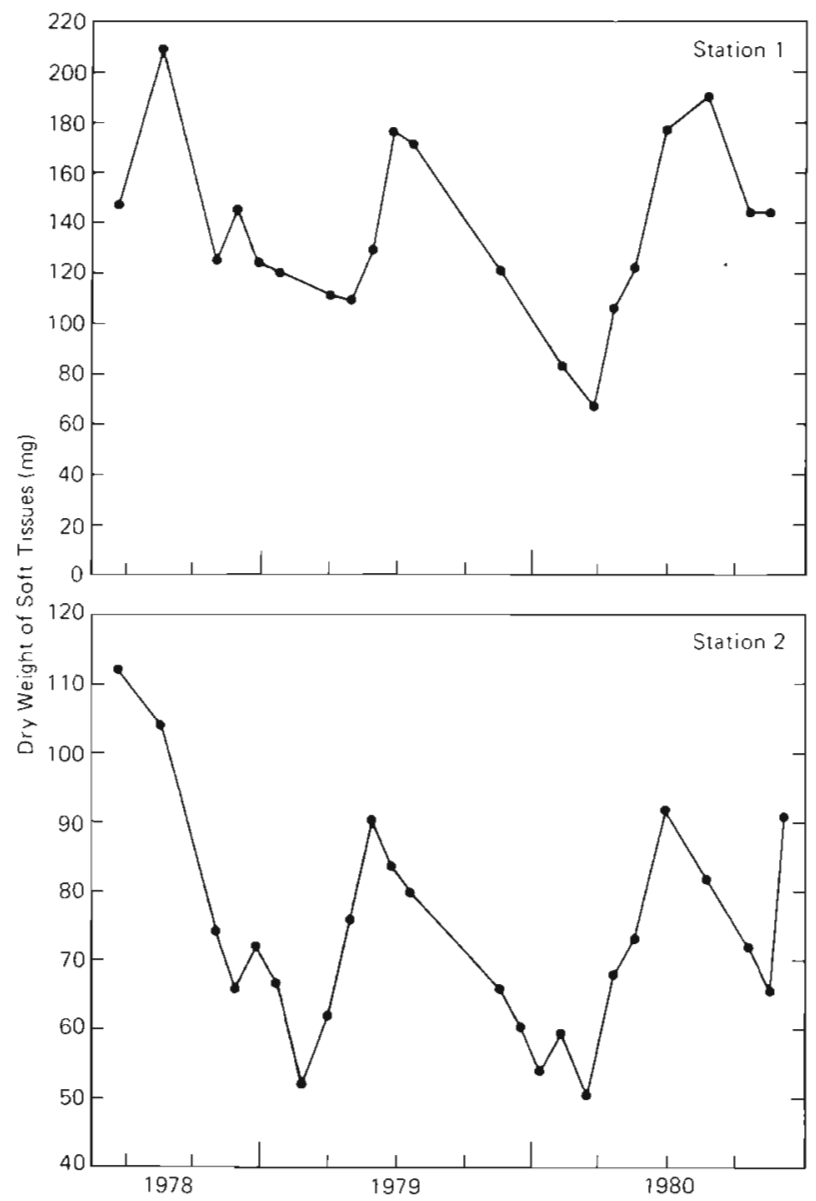

$=$ the dry weights of the standard-sized clam at $\mathrm{j}$ and $j+1$. Based upon Eq. 3, Eq. 4 can be reduced to the following form:

$$
\left(\frac{\hat{\mathrm{M}}}{\mathrm{W}}\right)_{j+1}=\frac{\mathrm{M}_{\mathrm{j}}^{*}}{\mathrm{~W}_{j+1}^{*}}
$$

When $M_{j}^{*}=M_{j+1}$ then $\left(\frac{\hat{M}}{W}\right)_{j+1}=\left(\frac{\bar{M}}{W}\right)_{j+1}$. Net metal exchange between $j$ and $j+1$ was expressed as concentration, $\mu \mathrm{g} \mathrm{g}^{-1}$, by dividing the difference in metal contents, $\Delta \mathrm{M}^{*}$, by the dry weight of the standard-sized clam at $\mathrm{j}+1$ :

$$
\frac{\Delta M^{*}}{W_{j+1}^{*}}=\frac{M_{j+1}^{*}-M_{j}^{*}}{W_{j+1}^{*}}
$$

The sum of $\frac{\Delta \mathrm{M}^{*}}{\mathrm{~W}_{\mathrm{j}+1}^{*}}$ and $\left(\frac{\hat{\mathrm{M}}}{\mathrm{W}}\right)_{\mathrm{j}+1}$ equals the observed metal concentration at $\mathrm{j}+1$ :

$$
\left(\frac{\overline{\mathrm{M}}}{\mathrm{W}}\right)_{j+1}=\left(\frac{\Delta \mathrm{M}^{*}}{\mathrm{~W}_{j+1}^{*}}\right)+\left(\frac{\hat{\mathrm{M}}}{\overline{\mathrm{W}}}\right)_{j+1}
$$

To compare the time series of observed mean metal concentrations with the time series that would be

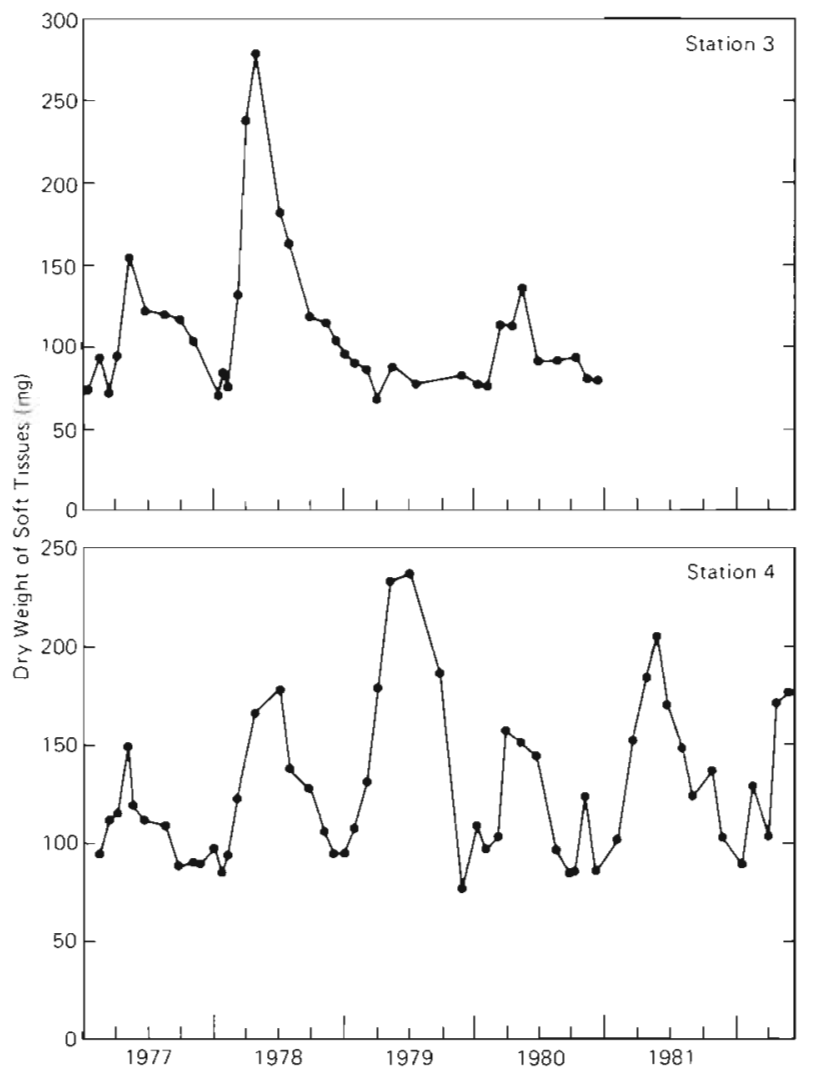

Fig. 3. Macoma balthica. Changes in dry weight of soft tissues of standard-sized specimens collected at 4 stations in San Francisco Bay between 1977 and 1981. Dry weights were calculated for a shell length of $25 \mathrm{~mm}$ except for Stn 2 where a shell length of $20 \mathrm{~mm}$ was used 
expected if all temporal fluctuations in metal concentrations were driven solely by changes in tissue weight, $M$; was held constant (i.e. it was assumed that no net uptake or loss occurred throughout the study period) and $W_{j+1}^{*}$ was varied according to the calculated values. The calculated concentrations varied reciprocally with $W_{j+1}^{*}$ and thereby approximated the relative magnitude of the effect of weight changes upon metal concentrations. However, the absolute differences between estimated concentrations were sensitive to the value of $\mathrm{M}_{\mathrm{j}}$. Therefore, the amplitude (but not the timing) of concentration changes were partly biased by the starting value. Although the choice of $\mathrm{M}_{\mathrm{j}}$ is arbitrary (depending upon where in the data set one wants to begin the calculations), we chose a relatively low concentration early in the time series for each station in order to (i) evaluate the entire data set and (ii) avoid exaggerating concentration differences between sampling dates.

\section{RESULTS}

The annual growth cycle of Macoma balthica in San Francisco Bay is characterized by a rapid increase in tissue weight during the spring (February through June) and a subsequent loss of weight throughout the summer and fall (Fig. 3; Nichols \& Thompson 1982). In the spring, tissue weight usually increased by a factor of about 2 , although variations in the degree of weight gain among stations and among years were common. For example, weight gains as great as 2.5 to $3 \times$ were observed at Station 3 in 1978 and Station 4 in 1979; in contrast, there was no measurable growth at Station 3 in 1979 .

Copper concentrations of soft tissues displayed both seasonal and year-to-year variations at each station (Fig. 4; Luoma et al. in press). Concentrations were usually highest in early winter, then declined to their lowest values in early summer (Fig. 4). The increase in
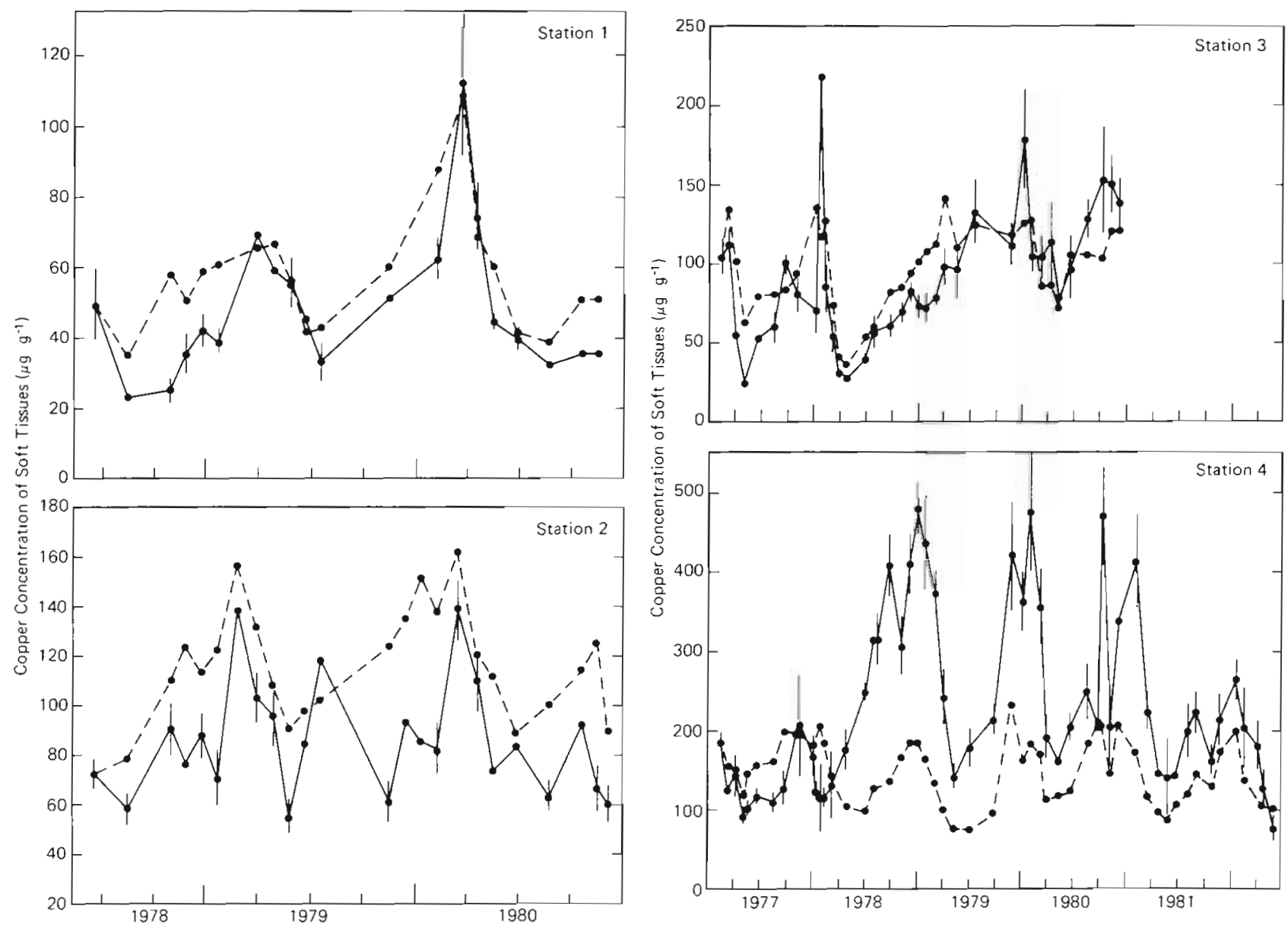

Fig. 4. Macoma balthica. Time series of copper concentrations of soft tissues of specimens collected at 4 stations in San Francisco Bay. Solid line: actual concentrations (mean $\pm 1 \mathrm{SE}$ ). Dashed line: concentrations driven by changes in tissue weight alone between sampling intervals (based upon the total $\mathrm{Cu}$ body content, $\mu \mathrm{g}$ ind $^{-1}$, of the initial sample) 
$\mathrm{Cu}$ concentrations often occurred when the weight of soft tissues was declining (Fig. 3 \& 4) while the decrease in $\mathrm{Cu}$ often coincided with tissue growth in the spring.

The agreement between the time courses of $\mathrm{Cu}$ concentrations predicted from changes in tissue weight and the observed $\mathrm{Cu}$ concentrations differed among stations (Fig. 4). The two agreed well at Stations 1 and 3, although the amplitudes of some peaks differed (e.g. Stn 1: Oct 1978; Stn 3: Feb 1978, Jan 1980). At Station 2 the rise and fall in $\mathrm{Cu}$ between May and November 1979 was not explained by weight change. At Station 4 , the predicted concentrations followed the trends in observed concentrations reasonably well during 1977 and after January 1981, but the effect of changing tissue weight could not explain the large fluctuations in $\mathrm{Cu}$ concentrations between 1978 and 1981. For all stations, in general, the time course of predicted concentrations followed the observed concentrations most closely when $\mathrm{Cu}$ concentrations were either relatively low or declining in the spring.

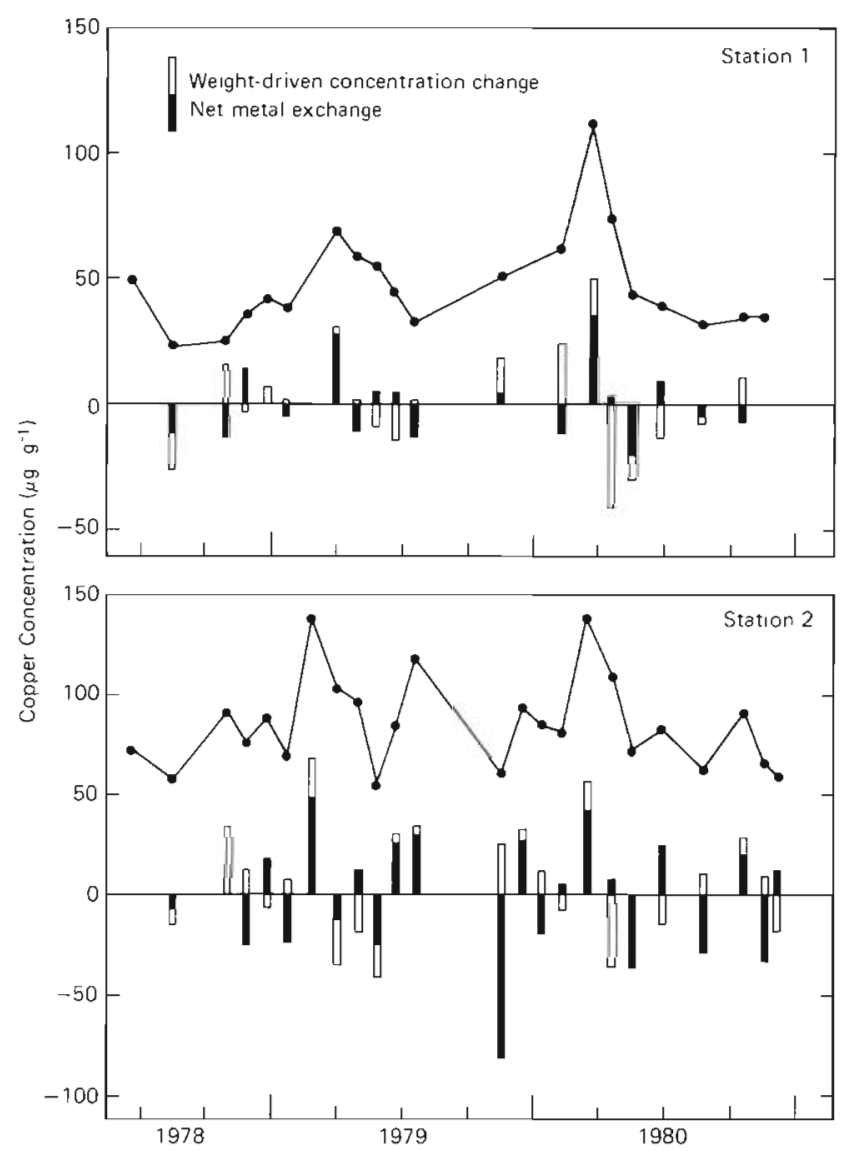

Fig. 5 quantitatively separates $\mathrm{Cu}$ concentration at each date into a weight-driven component and a net metal exchange component. Both components were involved in most changes in $\mathrm{Cu}$ concentration. Increases in weight were consistently important in determining the characteristics of the decline in $\mathrm{Cu}$ concentrations between January and May. Metal accumulation often coincided with weight losses in the fall accentuating increases in tissue $\mathrm{Cu}$ concentrations (e.g. Stn 1: Mar 1980; Stn 2: Feb 1979, Mar 1980; Stn 4: Dec 1978, 1979, 1980). A number of short periods of substantial accumulation followed by $\mathrm{Cu}$ loss also were identifiable. These included $\mathrm{Cu}$ peaks in April 1979 and March 1980 at Station 1 (although roughly $30 \%$ of the increase in $\mathrm{Cu}$ concentration in 1980 was due to a decrease in tissue weight), in February 1979 , June to August 1979 and March 1980 at Station 2 and in February 1978 and January 1980 at Station 3. Longer periods of $\mathrm{Cu}$ accumulation occurred at Station 4 . The dramatic increase in 1978 was caused by a 6 mo period of nearly continuous accumulation of Cu.. Although

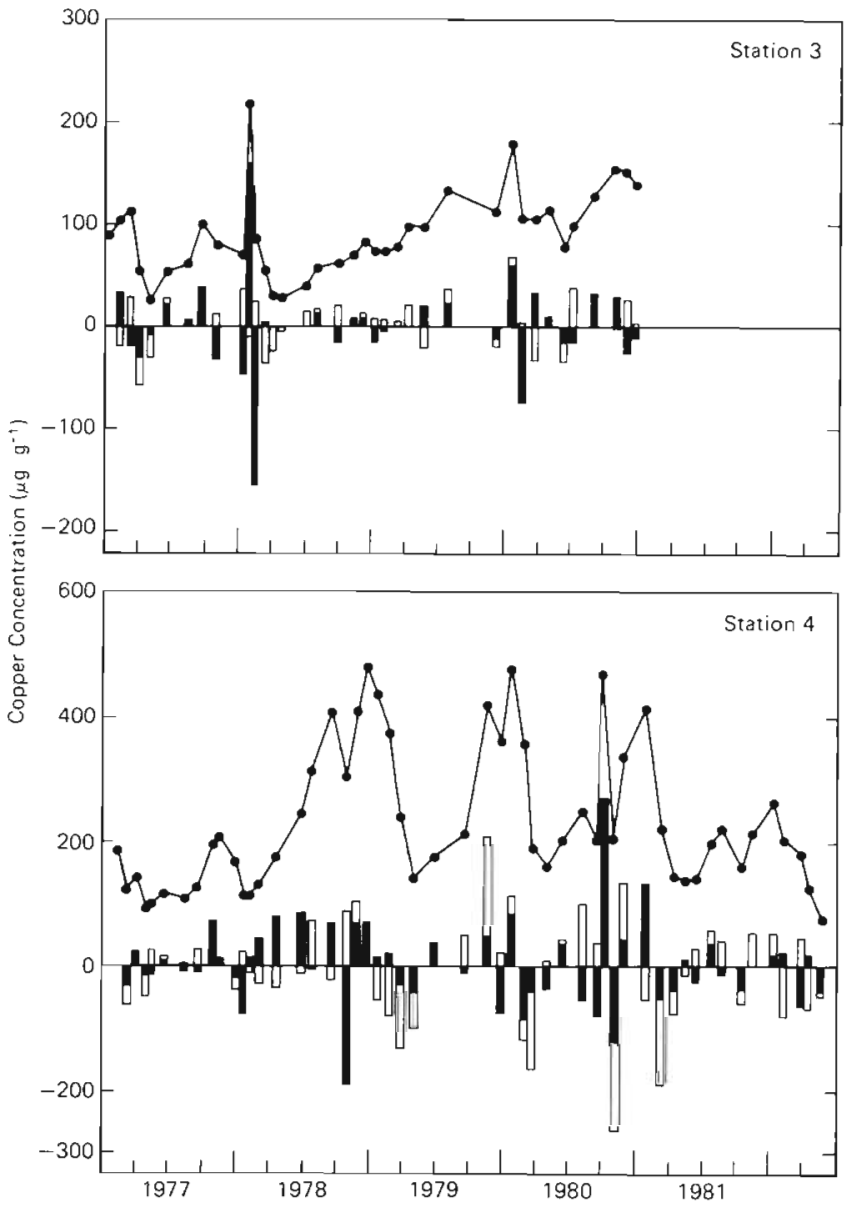

Fig. 5. Macoma balthica. Contribution of net Cu exchange (dark bars) and changes in tissue weight (open bars) to the variation in $\mathrm{Cu}$ concentrations of specimens at 4 stations in San Francisco Bay. Solid line: mean concentration of soft tissue. The change in concentration between samples is the additive result of metal accumulation (positive values) and loss (negative values) since the previous sampling date and the change in concentration affected by a change in the weight of soft tissues during the sampling interval. All values are $\mu \mathrm{g} \mathrm{g}^{-1}$ 
some $\mathrm{Cu}$ was subsequently lost, there was a net accumulation for that year. Thus, the decrease in $\mathrm{Cu}$ concentrations in the spring of 1979 was largely due to an increase in tissue weight. Concentrations increased later that year as that weight was lost. In 1980, there was again a small net accumulation of $\mathrm{Cu}$, but thereafter, losses exceeded accumulation and winter conyears.

Zinc did not exhibit seasonal fluctuations as strong as $\mathrm{Cu}$ (Fig. 6). Through much of the year, $\mathrm{Zn}$ concentrations were relatively stable, with elevated concentrations generally occurring for brief periods in the late winter and spring. The magnitude of annual $\mathrm{Zn}$ fluctuations was usually about $2 \times$, roughly the same as the yearly change in tissue weight (Fig. 6).

Predicted $\mathrm{Zn}$ concentrations followed trends in observed Zn concentrations most closely at Station 1 (Fig. 6) indicating that variations in $\mathrm{Zn}$ concentrations at that station were dominated by changes in tissue weight. At Stations 2, 3 and 4, some differences in trends and in the occurrence of specific peaks were observed. For example, at Station 3, peaks in Zn concentrations returned to levels characteristic of earlier

centration in February 1978, April 1979 and January 1980 occurred that were not predicted by weight change. Also at Stations 2, 3, and 4, concentrations predicted in the spring frequently decreased more repidly than those actually observed. Conversely in the summer and fall, when tissue weight decreased, predicted concentrations were often greater than observed. Differences between the observed and predicted $\mathrm{Zn}$ concentrations indicated that a significant portion of the $\mathrm{Zn}$ lost within any given year occurred in the summer/fall period (Fig. 7). The greatest accumulation of $\mathrm{Zn}$ was in the winter/spring (Nov to Mar), and frequently coincided with the period of rapid tissue growth. At Station 3, however, Zn peaks in 1978, 1979, and 1980 occurred before the commencement of tissue growth.

\section{DISCUSSION}

The degree to which seasonally varying tissue weight explained fluctuations in $\mathrm{Cu}$ and $\mathrm{Zn}$ concentrations in Macoma balthica differed markedly with location in San Francisco Bay and among years at a single

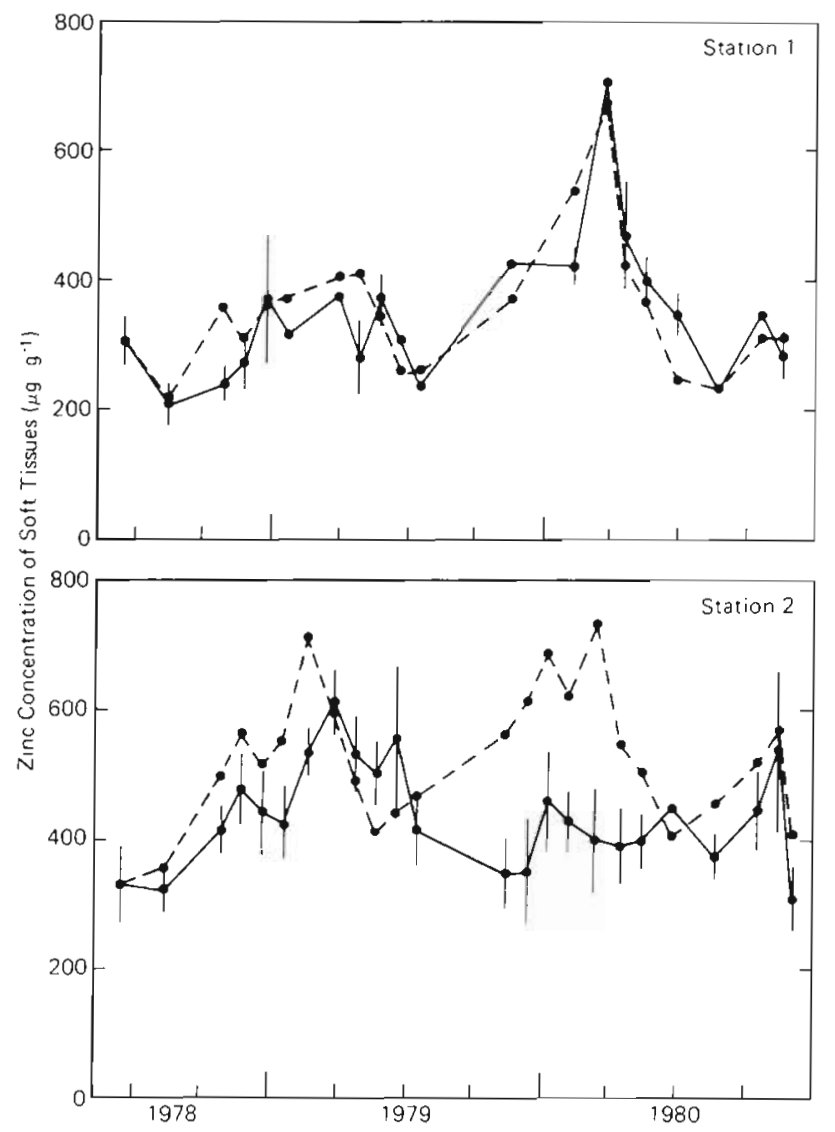

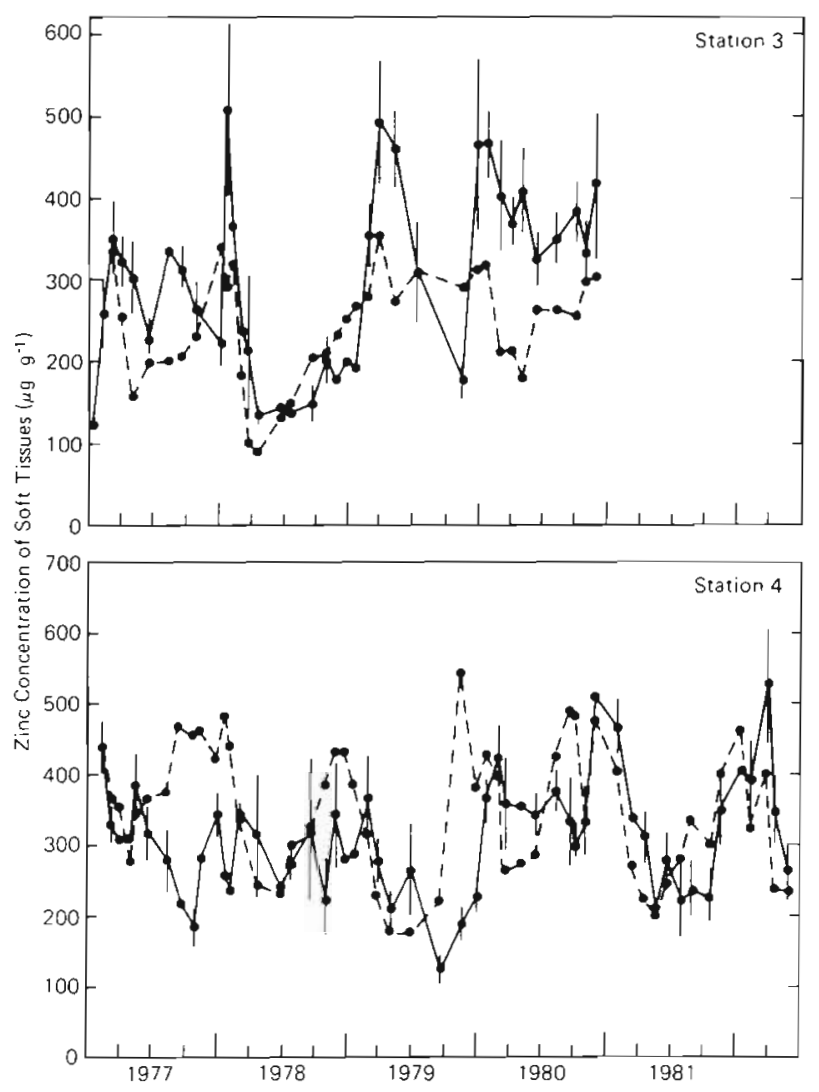

Fig. 6. Macoma balthica. Time series of zinc concentrations of soft tissues of specimens collected at 4 stations in San Francisco Bay. Solid line: actual concentrations (mean $\pm 1 \mathrm{SE}$ ). Dashed line: concentrations driven by changes in tissue weight alone between sampling intervals (based upon the total $\mathrm{Zn}$ body content, $\mu \mathrm{g}$ ind ${ }^{-1}$, of the initial sample) 

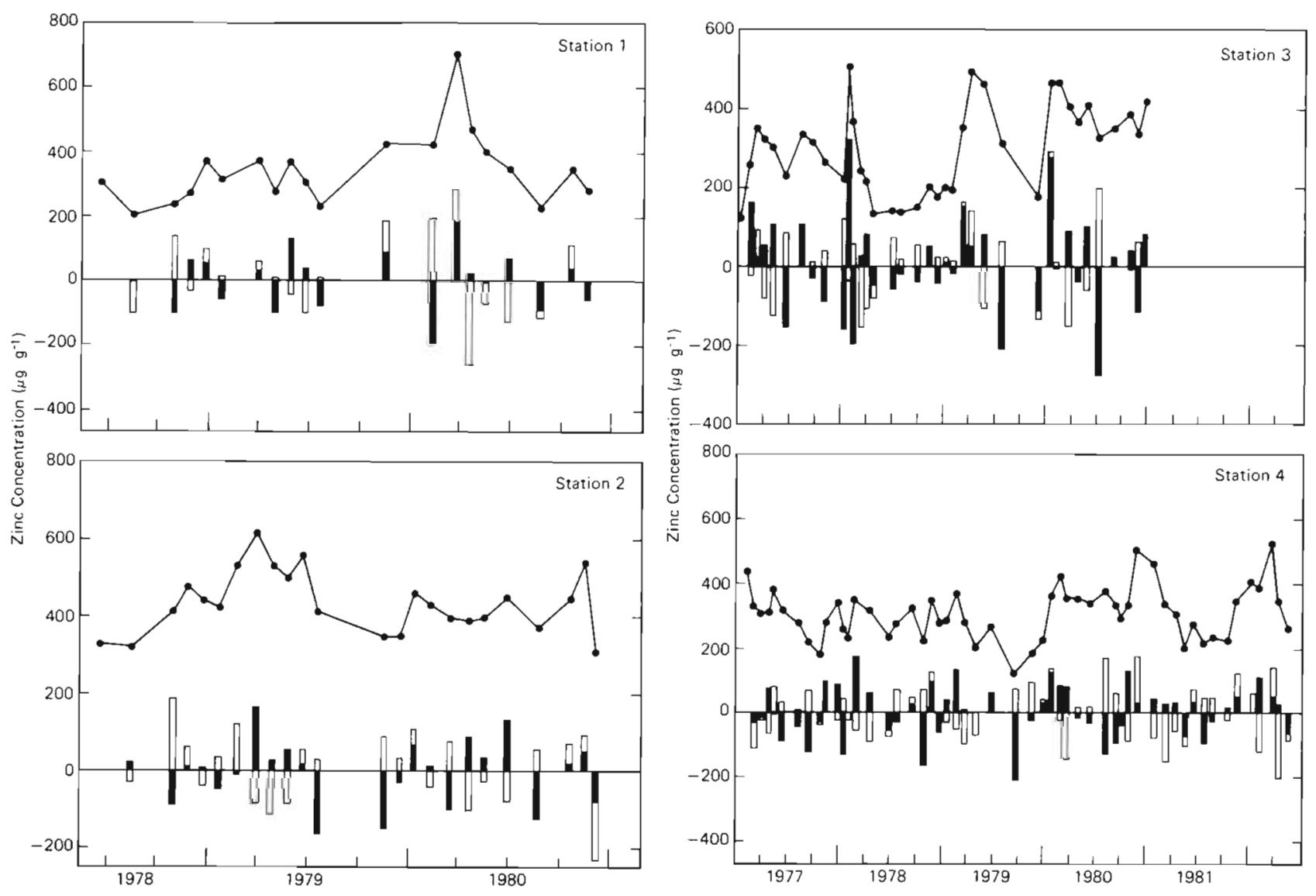

Fig. 7. Macoma balthica. Contribution of net Zn exchange (dark bars) and changes in tissue weight (open bars) to the variation in $\mathrm{Zn}$ concentrations of specimens at 4 stations in San Francisco Bay. Solid line: mean concentration of soft tissues. The change in concentration between samples is the additive result of metal accumulation (positive values) and loss (negative values) since the previous sampling date and the change in concentration affected by a change in the weight of soft tissues during the sampling interval. All values are $\mu \mathrm{g} \mathrm{g}^{-1}$

location. Differences between the 2 metals were also evident. $\mathrm{Cu}$ appeared to be more directly affected than $\mathrm{Zn}$ by the seasonal change in soft tissue. Temporal fluctuations in $\mathrm{Zn}$ concentration were generally not as variable as $\mathrm{Cu}$ and did not consistently display the strong seasonal pattern that would be expected if concentrations were driven by changing tissue weight.

Separating the influence of weight change allowed clearer identification of both short-term and long-term changes in net metal flux in the soft tissues of Macoma balthica. Of the several processes that could affect metal flux rates, changes in concentrations of biologically available metal (Bryan \& Hummerstone 1978, Jensen et al. 1981, Luoma 1983, Mason \& Simkiss 1983, Thomson et al. 1984) is probably the single most important. Biological processes associated with gonadal development (Cossa et. al. 1979) spawning (Lobel \& Wright 1982b, Zaroogian \& Johnson 1983), sex and age (Watling \& Watling 1976, Lowe \& Moore 1979), can also affect metal flux, but their influence is likely to be limited to relatively minor effects obscured by the individual variability within natural populations (Lobel \& Wright 1982a, b).

In nature, seasonal fluctuations in trace metal concentrations of animal tissues caused by changes in metal body burden are superimposed upon a background of variation driven by changes in tissue weight. Any single change in metal concentration may reflect either one or the simultaneous influence of both variables. The effect of weight-driven changes on trace metal concentrations can be significant (Phillips 1976, Simpson 1979, this paper) and if not accounted for, can seriously compromise results from organisms used as bioindicators to monitor contamination (Goldberg et al. 1978) or to study metal bioavailability (Whitfield \& Lewis 1976, Langston 1980, 1982, Luoma \& Bryan 1982).

The effect of seasonal growth on metal concentrations can be eliminated directly by converting concentration data to content, $\mu$ g ind ${ }^{-1}$ (Simpson 1979). However, this results in data in units that are not directly comparable with other environmental measurements, 
or are otherwise difficult to interpret (e.g. because the overall size of the organism involved cannot be considered, toxicological interpretations are more difficult). Alternatively, metal concentrations can be corrected for differences in tissue weight (Clifton et al. 1983, this paper). Our calculation of net metal exchange is derived directly from metal content and thus reflects changes in exposure. Although proportional changes may differ from changes in content where the weight of a standard-sized animal changes through time, the units will be in an easily interpretable form. Furthermore, the effect of weight change can be examined directly and independently.

Acknowledgements. The authors thank Drs. J. Cloern and J. Kuwabara for their comments on the manuscript. We also thank C. Johansson and E. Thomson-Becker for technical assistance and $\mathrm{S}$. Andrews for typing the manuscript.

\section{LITERATURE CITED}

Beukema, J. J., Cadee, G. C., Jansen, J. J. M. (1977). Variability of growth rate of Macoma balthica (L.) in the Wadden Sea in relation to availability of food. In: Keegan, B. F. Ceidigh, P. D., Boaden, P. J. S. (ed.) Biology of benthic organisms. Pergamon Press, New York, p. 69-77

Beukema, J. J., DeBruin, W. (1977). Seasonal changes in dry weight and chemical composition of the soft parts of the tellinid bivalve Macoma balthica in the Dutch Wadden Sea. Neth. J. Sea Res. 11: 42-55

Bryan, G. S., Hummerstone, L. G. (1978). Heavy metals in the burrowing bivalve Scrobicularia plana from contaminated and uncontaminated estuaries. J. mar. biol. Ass. U. K. 58: $401-419$

Clifton, R. J., Stevens, H. E., Hamilton, E. I. (1983). Concentration and depuration of some radionuclides present in a chronically exposed population of mussels (Mytilus edulis). Mar. Ecol. Prog. Ser. 11: 245-256

Cloern, J. E., Nichols, F. H. (1980). A von Bertalanffy growth model with a seasonally varying coefficient. J. Fish. Res. Bd Can. 35: 1479-1482

Cossa, D., Bourget, E., Piuze, J. (1979). Sexual maturation as a source of variation in the relationship between cadmium concentration and body weight of Mytilus edulis L. Mar. Pollut. Bull. 10: 174-176

Davis, J. P., Wilson, J. G. (1983). Seasonal changes in tissue weight and biochemical composition of the bivalve Nucula turgida in Dublin Bay with reference to gametogenesis. Neth. J. Sea Res. 17: 84-95

Gallucci, V. F., Hylleberg, J. (1976). A quantification of some aspects of growth in the bottom-feeding bivalve Macoma nasuta. Veliger 19: 59-67

Goldberg, E. D., Bowen, V. T., Farrington, J. W., Harvey, G., Martin, J. H., Parker, P. L., Risebrough, R. W., Robertson, W., Schneider, E., Gamble, E. (1978). The mussel watch. Environ. Conserv. 5: 101-125

Jensen, K., Randløv, A., Riisgard, H. U. (1981). Heavy metal pollution from a point source demonstrated by means of mussels, Mytilus edulis. Chemosphere 10:761-765

Lammens, J. J. (1967). Growth and reproduction in a tidal flat population of Macoma balthica (L.). Neth. J. Sea Res. 3: 315-382
Langston, W. J. (1980). Arsenic in U. K. estuarine sediments and its availability to benthic organisms, $J$, mar. biol. Ass. U. K. $60: 869-881$

Langston, W. J. (1982). The distribution of mercury in British estuarine sediments and its availability to deposit-feeding bivalves. J. mar. biol. Ass. U. K. 61: 667-684

Lobel. P. B., Wright, D. A. (1982a). Relationship between body zinc concentration and allometric growth measurements in the mussel Mytilus edulis. Mar. Biol. 66: 145-150

Lobel, P. B., Wright, D. A. (1982b). Gonadal and nongonadal zinc concentrations in mussels. Mar. Pollut. Bull. 13: 320-323

Lowe, D. M., Moore, M. N. (1979). The cytochemical distributions of zinc ( $\mathrm{Zn}$ II) and iron (Fe III) in the common mussel, Mytilus edulis, and their relationship with lysosomes. $\mathrm{J}$ mar. biol. Ass. U. K. 59: 851-858

Luoma, S. N. (1983). Bioavailability of trace metals to aquatic organisms - a reviev. Sci. Total Environ. 28: 1-22

Luoma, S. N., Bryan, G. W. (1982). A statistical study of environmental factors controlling concentrations of heavy metals in the burrowing bivalve Scrobicularia plana and the polychaete Nereis diversicolor. Estuar. coast. Shelf Sci. 15: $95-108$

Luoma, S. N., Cain, D. J. (1979). Fluctuations of copper, zinc and silver in tellinid clams as related to freshwater discharge - south San Francisco Bay. In: Conomos, T. J. (ed.) San Francisco Bay: the urbanized estuary. Allen Press, Kansas, p. 231-246

Luoma, S. N., Cain, D., Johansson, C. (in press). Temporal fluctuations of silver, copper and zinc in the bivalve Macoma balthica at five stations in South San Francisco Bay. Hydrobiologia

Martin, N., Ichikawa, G., Goetzl, J., de los Reyes M., Stephenson, M. D. (1984). Relationships between physiological stress and trace toxic substances in the bay mussel, Mytilus edulis from San Francisco Bay, California. Mar. Environ. Res. 11: 91-110

Mason, A. Z., Simkiss, K. (1983). Interactions between metals and their distribution in tissues of Littorina littorea (L.) collected from clean and polluted sites. J. mar. biol. Ass. U. K. 63: 661-672

Nichols, F. H., Thompson, J. K. (1982). Seasonal growth in the bivalve Macoma balthica near the southern limit of its range. Estuaries 5: 110-120

Phillips, D. J. H. (1976). The common mussel Mytilus edulis as an indicator of pollution by zinc, cadmium, lead and copper. I. Effects of environmental variables on uptake of metals. Mar. Biol. 38: 71-80

Popham, J. D., D'Auria, J. M. (1983). Combined effect of body size, season, and location on trace element levels in mussels (Mytilus edulis). Archs environ. Contam. Toxicol. 12 $1-14$

Simpson, R. D. (1979). Uptake and loss of zinc and lead by mussels (Mytilus edulis) and relationships with body weight and reproductive cycle. Mar. Pollut. Bull. 10: 74-78

Strong, C. R., Luoma, S. N. (1981). Variations in the correlation of body size with concentrations of $\mathrm{Cu}$ and $\mathrm{Ag}$ in the bivalve Macoma balthica. Can. J. Fish. Aquat. Sci. 38: 1059-1064

Thomson, E. A., Luoma, S. N., Johansson, C. E., Cain, D. J. (1984). Comparison of sediments and organisms in identifying sources of biologically available trace metal contamination. Wat. Res. 18: 755-765

Watling, H. R., Watling, R. J. (1976). Trace metals in Choromytilus meridionalis. Mar. Pollut. Bull. 7: 91-94 
Whitfield, P. H., Lewis, A. G. (1976). Control of the biological availability of trace metals to a calanoid copepod in a coastal fjord. Estuar, coast. mar. Sci. 4: 255-266

Zandee, D. I., Kluytmans, J. H., Zurburg, W., Pieters, H. (1980). Seasonal variations in biochemical composition of
Mytilus edulis with reference to energy metabolism and gametogenesis. Neth. J. Sea. Res. 14: 1-29

Zaroogian, G. E., Johnson, M. (1983). Copper accumulation in the bay scallop. Argopecten irradians. Archs environ. Contam. Toxicol. 12: 127-133

This paper was presented by $\operatorname{Dr}$ G. W. Bryan; it was accepted for printing on October 21, 1985 